This is an Open Access article, distributed under the terms of the Creative Commons Attribution licence (http://creativecommons.org/licenses/by/4.0/), which permits unrestricted re-use, distribution, and reproduction in any medium, provided the original work is properly cited.

\title{
Ship Mounds Matter: The Referential Qualities of Earth-Sourced Materials in Viking Ship Mounds
}

\author{
Rebecca J.S. Cannell \\ Department of Archaeology, Conservation and History, University of Oslo, Norway
}

\begin{abstract}
This article discusses the construction details of the mounds erected over large Viking ship burials in Norway and shows that they form an integral part of mortuary practice. Moreover, elements of the construction that are potentially unique to this type of monument are repeated, suggesting a knowledge of the properties of materials and their inter-relationships within the mounds. Here, referencing between and within the mounds is considered alongside the connections these soils, sediments, and other earth-sourced materials contained in relation to the cultural landscape. The selection of such materials and the location of the burials in the landscape were fundamental to the creation of a performative scene for the burial rites, and for establishing a desired, interlinked, social memory.
\end{abstract}

Keywords: Viking Age, burial mounds, archaeological soils, Viking ships, Norway, referentiality

\section{INTRODUCTION}

Burials under mounds of earth or stone constitute the largest fraction of the evidence for mortuary customs in Viking Age Scandinavia that has survived. The presence of a ship as part of the burial is a particularly striking form of burial mound construction, or mortuary practice. Although there are approximately 350 burials with boats known in Norway from the period between AD 700 and 1050 (Aannestad \& Glørstad, 2017), ship burials, namely burials with ships over fourteen metres long, are few (for a discussion of definitions and sizes of vessels from the period, see Bill, 2019, with references). In this article, I consider selected ship burials as an avenue to explore the complexity of mound construction in this period. The main focus is on how, from the perspective of their materiality and the performative nature of their construction, these burials may be linked via the relationships created by their physical creation. The examples chosen are the burials of Gokstad, Oseberg, Tune, Storhaug, and Grønhaug, all located in southern Norway and dated to the Viking Age (here AD 800 to 1050) or just before (Figure 1). Dendrochronological dating and timber provenance studies clearly connected these five sites (Bonde \& Stylegar, 2009, 2016), as does the presence of a substantial, unburnt ship burial under an earthen mound.

The similarities in the materials used in the mound construction of Storhaug, Sølushaugen (located beside Storhaug), Grønhaug, and Oseberg were noted by Shetelig in 1912 (Shetelig, 1912: 222). Terje Gansum has broadened these observations in his assessment of the complexity of Viking Age burial mound construction, particularly in his work on the Oseberg 


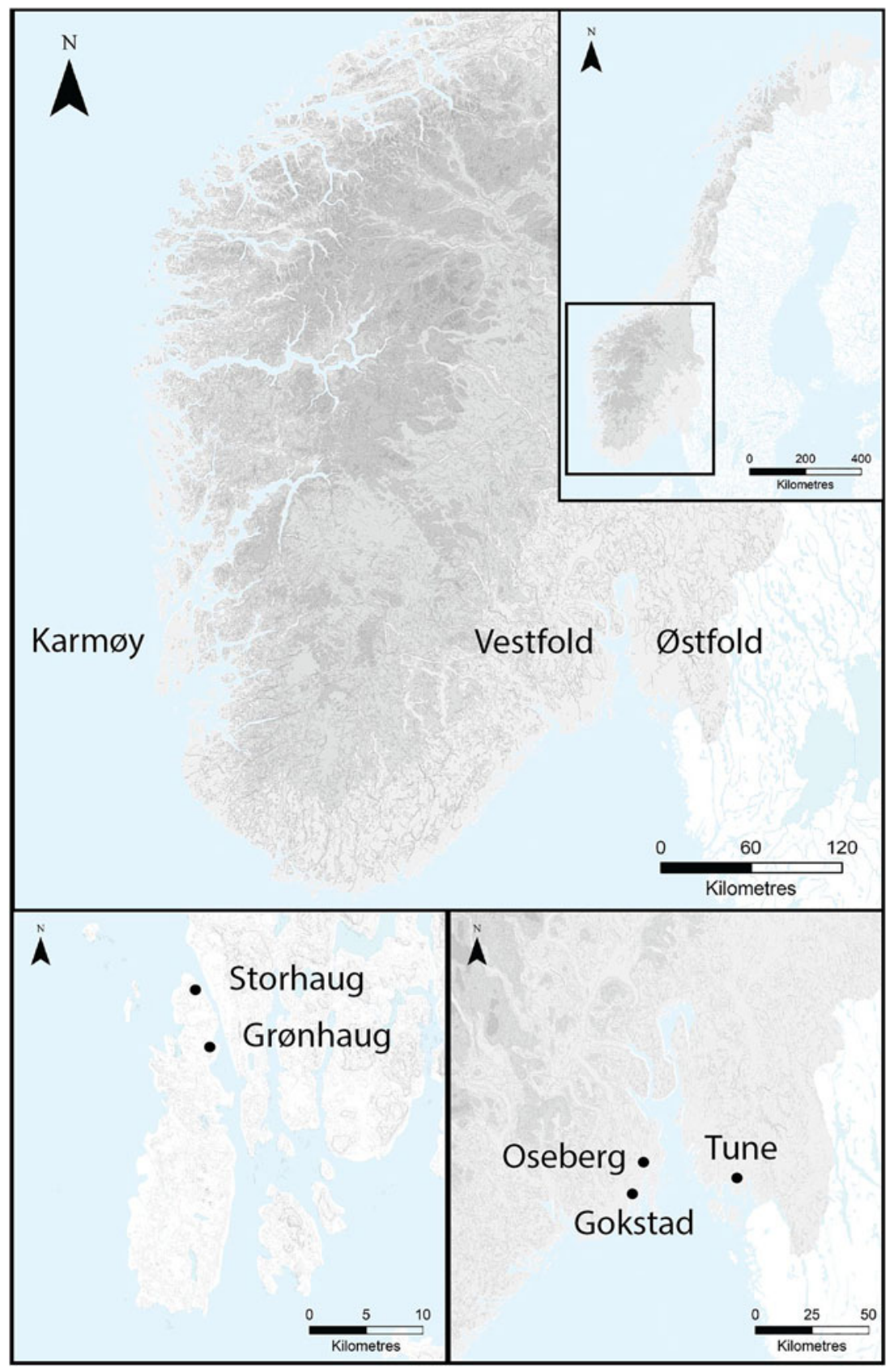

Figure 1. Location map with places named in the text.

Map source: Norwegian Mapping Authority, Geoveskst and Municipalities, 2020.

burial, considered in detail below (Gansum, 2002, 2004b). A fresh examination of mound construction details and an attempt to set mound building within the performative arena of funerary rites in the Viking Age are presented here.

Burial mounds are a central source of evidence for the past, and this article 
considers how they were made, what they were made of, and how this potentially connected the mounds to each other, and to the landscape in differing ways. By looking at the materials of the mounds themselves, rather than the objects accompanying the deceased, new avenues for exploring the past can be opened and these may have implications beyond ship burials. Many known burial mounds were excavated some time ago, with different (and now superseded) standards of excavation and recording. The primary focus of these older excavations was on the grave goods and portable objects, and consequently the environmental context and the mound materials received less scrutiny. Nonetheless, larger, more impressive burial mounds tended to be better documented than smaller barrows and/or burials with fewer grave goods. Hence the large monuments are better suited to retrospective studies such as this.

More recent results supplement this review. Within the current Gokstad Revitalised project, the intact flanks of the Gokstad burial mound were cored, revealing details that document the intricacy of the mound. As will be discussed below, the burial was constructed by digging a trench for the ship, and then deliberately piling up layers of soil from the dug area, along with soils collected from the vicinity, which were kept separate throughout. This deliberate layering of contrasting soils and sediments, alongside other aspects, such as the creation of planned access points to the burial, suggests that the mound was a central element in the burial and provided a 'stage' for the funerary rituals (Cannell et al., 2020). This wealth of detail is currently not available for other ship burials, for want of modern sediment records and analysis. Nevertheless, aspects of the construction materials used in comparable mounds illustrate that mound building was an essential part of burial expression.
The theoretical impetus for this review of burial mounds is largely drawn from Andrew Meirion Jones's recent publications exploring relational and performative processes in human interactions with materials. This approach considers human actions as part of a process of performance in tandem with materials, which provoke and convey human responses via their physical properties. It is an alliance that cannot be reduced to material or human agency alone (Jones, 2012: 12-13), echoing Barad's (2007: 152) generated and generative properties, and the performative nature of matter. In this, materials are part of human performance, and are used creatively. To this we can add improvisation and experimentation, and repetition of actions, which are thus redefined and recreated in a new way (Jones, 2012: 19, 102-04). In performance, the past is used in a referential way, or cited, via the humans and materials involved (Jones, 2007: 86). In funerary situations, creation and remembrance are enacted via the physical properties of the materials, their referential or citation properties, and the way they are engaged in the performance (Jones, 2007: 49).

Influences and intersections between the regions of the interconnected northern European world of the time have left their mark on mortuary rites, visible in the range of practices documented (Price, 2012; Williams, 2016). The diversity and plurality of Viking Age burial customs is considered to form part of creative acts that are broadly relatable from a social standpoint, whilst allowing for individual expressions. In oral societies, such as Viking Age Scandinavia, stories and traditions were repeated bodily performances, with spatial aspects, materials, and shared experiences all key to the performance and memory creation (Williams, 2006; Back Danielsson, 2007: 29-39). This oral tradition may have involved movement to and 
between liminal spaces in performances (Gunnell, 2006), and this can be connected to the performances of burial customs (Price, 2010, 2014). The burial was akin to an oral performance, involving human and material participation to reiterate, reference, and relate the story to the deceased, the community, and/or wider myths and shared experiences (Price, 2012, 2014). As the scant contemporary written sources suggest, high-status funerals at this time were lengthy and complex acts, orchestrated with purpose and direction (Price, 2012), creating a sense of a scene. Whilst I cannot decipher the precise sequence of mound construction in the burials selected here, I aim to show that mound construction, as a performance, was an essential aspect of Viking Age mortuary behaviour. Moreover, the materials used were part of creating a scene with referential and relational connotations to other graves, the wider landscape, and shared traditions and myths.

\section{The Earth-Covered Ships of Viking Age Norway}

Since this article is primarily concerned with mound building, a full inventory of Gokstad and Oseberg is not given here; suffice to say the graves are amongst the richest and best-preserved of the period. Both graves contained a large, ocean-going ship (at Gokstad, the so-called King's Mound contained three smaller boats in addition to the ship) with a burial chamber placed behind the mast, and a wealth of grave goods within and without the ship, including sleds, cooking equipment, furniture, sacrificed animals, and imported objects.

Ever since the excavations of Gokstad in 1880 and of Oseberg in 1904 (Nicolaysen, 1882; Brøgger et al., 1917), the ships and grave goods have been the focus of archaeological enquiry. Research on impressive burial mounds such as these has tended to concentrate on power and politics, as well the belief systems and rituals implied by the burial customs (e.g. Christensen, 1959; Thoresen, 1980; Seal, 2003; Nordeide, 2011; Bill \& Daly, 2012; Dobat, 2015; Aannestad \& Glørstad, 2017; Bill, 2019). In many cases, the finds, including the spectacular ships, are the prime focus of research (e.g. Bonde \& Christensen, 1993; Vedeler, 2011; Pedersen et al., 2016; Bill, 2016; Bonde \& Stylegar, 2016), or the human remains themselves (Holck, 2006, 2009). The mounds, however, have received much less scholarly attention. Once excavated and partly removed, in some respects they ceased to be considered part of the grave.

After excavation, the Gokstad and Oseberg mounds lay open for several decades before later reconstruction work, whilst the finds and ships were conserved and housed in a specially constructed museum (now the Viking Ship Museum in Oslo). Nicolay Nicolaysen excavated the Gokstad ship in 1880, and in its publication, he briefly describes the mound composition, albeit in purely practical terms (Nicolaysen, 1882). Some twenty-four years later, Gabriel Gustafson and Haakon Schetelig left far more primary documentation of their excavation of the Oseberg mound, and included botanical, zoological, and geological experts in their strategy (Brøgger et al., 1917; Holmboe, 1917; Nordeide, 2011). These records have formed the basis for later speculation and interpretation, most notably Gansum's interpretation and striking visual reconstruction of the Oseberg mound, discussed below.

Oseberg and Gokstad are not the only ship burials under earthen mounds known from Norway: Borre in Vestfold and the Tune ship under the mound at Haugen in Østfold are other examples, as are Storhaug and Grønhaug on Karmøy 
on the south-west coast. All these burials are dated to the Viking Age (here $\mathrm{AD}$ 800-1050) or immediately before, primarily via dendrochronology. There are undeniable physical connections between these burials: the Oseberg ship was built from timbers felled in the same area as the Storhaug and Grønhaug ships, and the beech used for ornamentation on Oseberg probably came from the west coast of Norway. One of the small boats from Gokstad was also built from timbers with the same west-coast origin (Bill \& Daly, 2012; Bonde \& Stylegar, 2016). There are striking similarities in the use of a burial chamber, in the artefacts, and the later plundering of graves (Bill \& Daly, 2012; Bill, 2017), making it fertile ground for further comparison.

\section{The Karmøy Burials}

When considering the mounds alone, we can highlight some of the connections and similarities between them whilst also emphasizing differences, beginning with the earlier examples on the island of Karmøy. This west-coast island is located on a narrowing of the sea-route that stretches up the coast of Norway. Overlooking the sound is the site of Avaldsnes, with historical and archaeological links to high-status settlements in the pre-Viking and Viking periods (Mundal, 2018; Skre, 2018).

Grønhaug, erected (or rebuilt) after $\mathrm{AD} 779$, is situated at the end of a line of several substantial Bronze Age burial mounds at Reheia. These Bronze Age mounds form part of a larger cemetery but we can only speculate whether the Viking Age ship burial is a re-used Bronze Age mound, or whether it was built to manifest an association with these earlier mounds (Gansum, 2004b: 176). The mound in question had a diameter of at least $30 \mathrm{~m}$ and consisted of an earthen capping over a central cairn and kerbing stones. These construction details suggest a possible Bronze Age origin, since several excavated Bronze Age burial mounds on Karmøy (e.g. Kubbhaug) have an inner cairn, kerbing, and an earthen covering to the cairn. A nineteenth-century source mentions that a stone cist burial had been present in the upper mound material, although it remains undated (Opedal, 1998: 22-28). A recent re-evaluation of the nearby site of Flagghaug suggests that this substantial mound was a re-used Bronze Age burial mound with an inner cairn and secondary graves from the Roman Iron Age and Viking period (Stylegar \& Reiersen, 2018). Returning to the ship burial in Grønhaug, the ship was placed centrally to the burial, but only to a depth of one metre into the inner cairn, leaving a further metre of cairn beneath the ship. This positioning in the cairn rather than under it adds weight to the hypothesis that this was a re-used monument.

The re-use of a burial, or deliberate association with it, is often interpreted as a means of legitimizing presence and authority, sculpting identity, and inferring mythical origins of those interred (Williams, 1998; Thäte, 2007: 277-80). In the present case, the purposeful alignment with substantial Bronze Age mounds, or the direct re-use of one, can be viewed as a connection to a past, whether idealized or not. Richard Bradley (amongst others) contends that people in the past had little means of assigning age to a humanmade object in the landscape, and encounters with older monuments would have involved reinterpretation, reinvention, and negotiation (Bradley, 2002, 2015). Moreover, the use of the earth itself, and earth connected physically with the past, could create regenerative bonds between past and present through the physical proximity and unique regenerative properties of soil (Given, 2018). 
Assuming it was an older mound, the sequence of creating the Viking Age burial at Grønhaug would be as follows. First, the soil and sediment were dug through, and then part of the Bronze Age cairn was removed to create a trough in the stones (Figures 2 \& 3). This was then partly covered with grey sands and charcoal, and the $c .15$ metre-long ship was placed in this (Opedal, 1998: 24-25). Shetelig (1902) observed that the grave had been plundered in antiquity and hence many details have been lost. A wide range of organic materials had, however, been collected, such as moss and birch bark placed over the deck, which was then filled with grassland turf and peat or wetland turf (myrjord in the original). The four-metre high mound was then built with turf and peat sods with pockets of gravel and sand (Opedal, 1998: 24-27). It is impossible to ascertain whether the description of the upper mound relates to the ship burial or to earlier phases, particularly in light of a later break-in that obscured its stratigraphy.

Storhaug is located less than two $\mathrm{km}$ from Grønhaug, also on the northern side of Karmøy, overlooking the strait. It was initially dated through a series of ${ }^{14} \mathrm{C}$ dates to $\mathrm{AD}$ 680-800 and was considered likely to belong to the period $\mathrm{AD}$ from 680-750 (Opedal, 1998: 65). New dendrochronological data now place the burial in or after $\mathrm{AD} 779$ (Bonde \& Christensen, 1993; Bonde \& Stylegar, 2016), making it almost contemporary with Grønhaug. Excavated in 1887 by Lorange, the notes from the excavation suggest that the ship was placed in a prepared trench, and that some sinkage had occurred when the cavities in the grave had collapsed (Lorange, 1888).

The notes available suggest a complex construction using earth-sourced materials

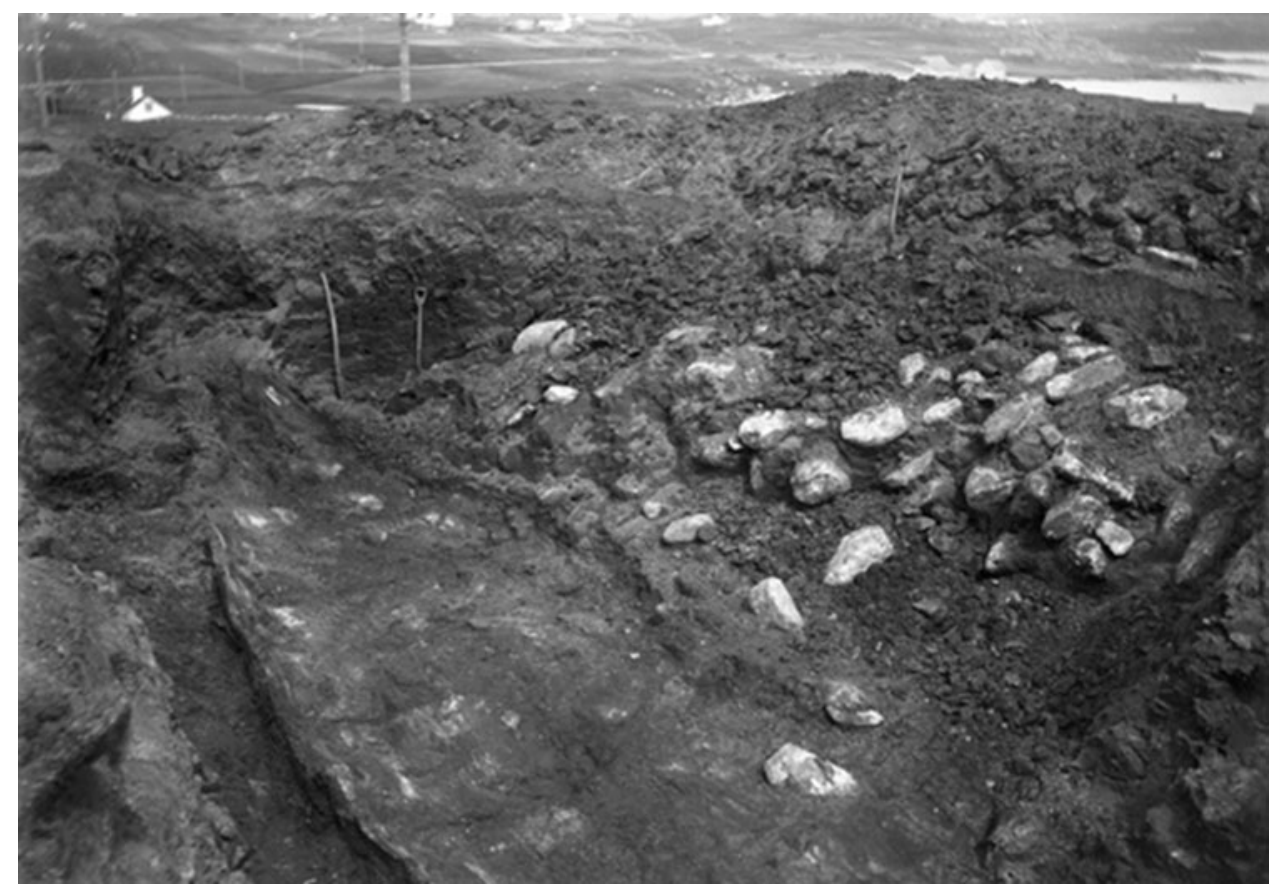

Figure 2. Photograph showing the outline of the ship found in Gronbaug during excavation. (C) 2020 University Museum in Bergen, CC BY-NC-ND 3.0 
GRøNHAUG

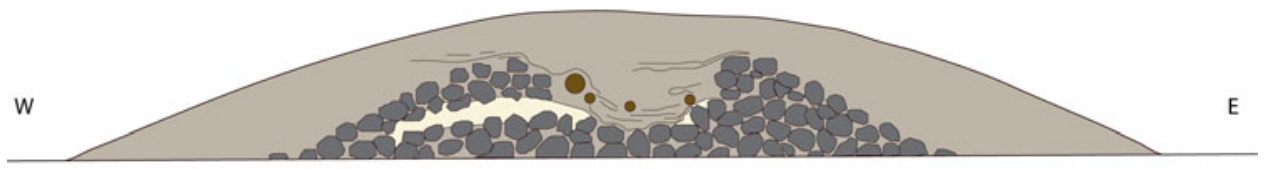

Stone cairn
$\square$ Mound turf and peat
$\square$ Grey sand layer
$-\quad$ Timbers
$-\quad$ Sand lens?

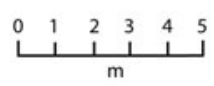

- Sand lens?

Figure 3. Section through Gronhaug (after Shetelig, 1902:5, fig. 1).

gathered from the surrounding landscape, resulting in a mound of considerable size and complexity (Figures $4 \& 5$ ). The area under the mound is described by Lorange as peaty turf, upon which heather turves were placed upside down over the buried surface. Above this, the body of the mound was built of horizontal layers of reddish-yellow clay loams, peat sods, and thick layers of charcoal. The charcoal layers are described as dumps that thinned to the sides, and in places these were up to a metre thick, which is in itself quite remarkable. Opedal (1998: 15, 42-43) postulates, after Lorange (1888), that the construction was designed to enhance preservation, although she later notes that this alone cannot explain the thick charcoal deposits. At Storhaug, Lorange found several small, sharpened stakes and the ship was edged with six pairs of worked upright stones (Opedal, 1998: 15-17).

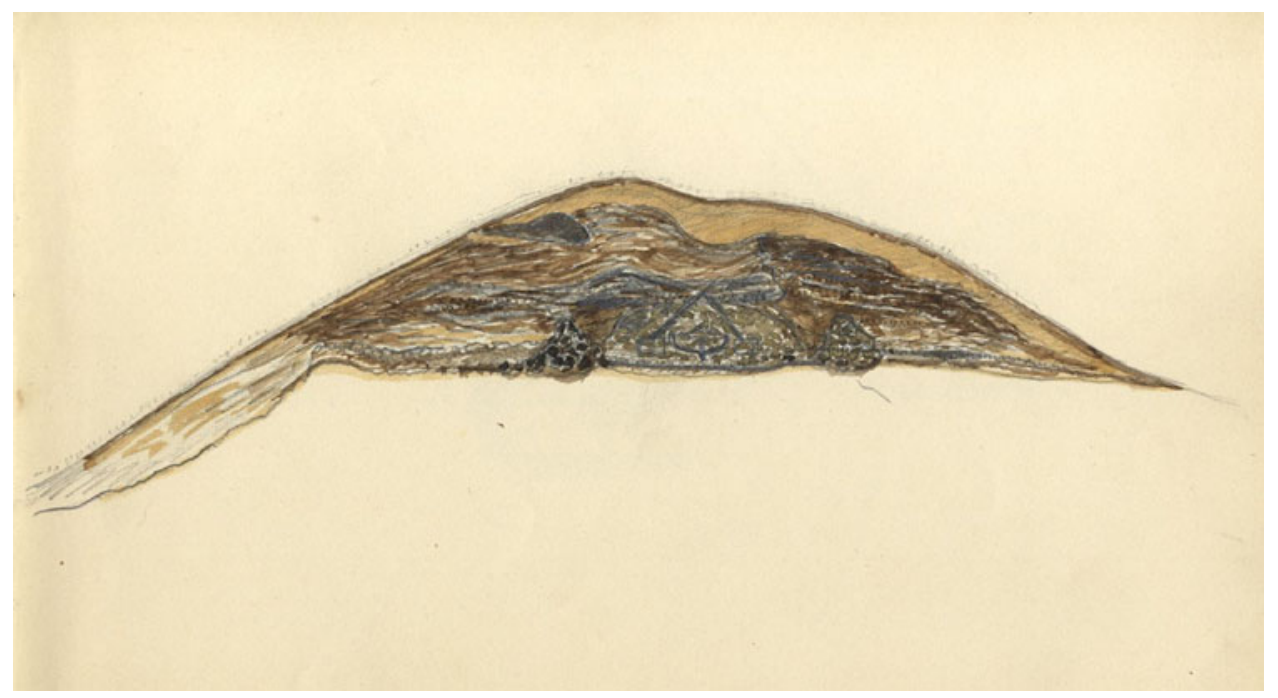

Figure 4. Water colour drawing of a section through Storhaug by A. Lorange. Photo: University Museum, Bergen, the original is in private ownership. Reproduced with permission from the University Museum, Bergen. 


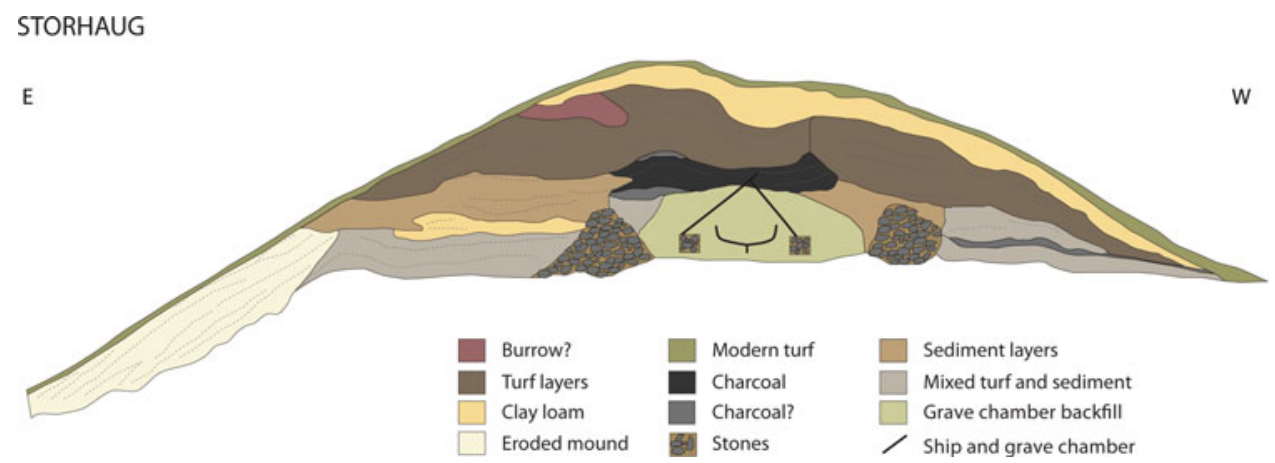

Figure 5. A reinterpretation of the section through Storhaug, based on Figure 4.

These were interpreted in practical terms, the stakes being set to measure and build the mound, and the paired slabs to support the ship.

The geology, geomorphology, and resulting soils on Karmøy are highly varied, and the materials present in the mounds could easily have been sourced on the island, though not all from the immediate vicinity. Five per cent of the land is currently classified as wetlands, although there is evidence for the creation and maintenance of organic rich, plaggic horizons for agriculture in the pre-Viking period (Acksel et al., 2019). The wetlands would be a source of peats, the cultivated soils have similarities to the soils used to construct the burial mounds at Borre, Vestfold (Myhre, 2015: 66, 73). The variety of sediments used suggest an intimate knowledge of the underlying soils, together with an explicit intention of using them when building the mound. By collecting materials for the mound, references to the complexity of the wider landscape were made. The array of materials, from rich black peat sods to gravels and loams, as well as the charcoal, would have created striking visual contrasts as the mound was built in distinct layers.

Storhaug and Grønhaug differ in their construction; one is potentially a re-used mound, the other is 'purpose built'. Significantly, both use a variety of soils, sediments, and plant materials brought to the burial from across the landscape, and both contain charcoal layers. Moreover, the construction of Storhaug appears to have involved removing part of the land surface prior to constructing the mound.

From these early Karmøy graves, let us move east to the famous, slightly later, mounds in Vestfold in southern Norway, and, by comparing their construction, illustrate that the threads that connect them extend beyond the grave goods to the mounds themselves.

\section{The Vestfold Burials}

Whilst the Vestfold burial mounds discussed here were also excavated over one hundred years ago, much more documentation is available. Gustafson and Schetelig left extensive notes, illustrations, publications, and photographs from their 1904 excavation of Oseberg (Brøgger et al., 1917). Nicolaysen's 1880 excavation of Gokstad left fewer records of the mound, but the results were published shortly after excavation. Furthermore, the current 'Gokstad Revitalised' project at the Museum of Cultural History in Oslo has greatly increased our knowledge of the 
burial, its cultural context, and wider landscape setting (Nicolaysen, 1882; Bill \& Daly, 2012; Bill, 2013; Macphail et al., 2013; Cannell et al., 2020).

\section{OSEBERg AND GoKSTAD}

Oseberg is chronologically the earliest of the Vestfold group, dated to c. AD 834, some forty to fifty years or so after Grønhaug and Storhaug (Bonde \& Stylegar, 2016). As noted, Gansum published a striking reinterpretation of the Oseberg burial (Figure 6), following his own research into documented observations made during the original excavation. His reinterpretation suggests that the mound was left open in the form of a stage for a period (Gansum, 2002, 2004b: 171-74). This is based on a break in stratigraphy between the stacked turf, which was noted during excavation as a line stretching from one side of the ship to the other, over the burial chamber (Brøgger et al., 1917: 136-37). The amount of time the grave was left open was estimated from the suggestion that both spring flowering and autumn fruits were present in the burial, implying that burial took place over weeks if not months. Nordeide (2011) has, however, challenged this reading of the sequence after a thorough re-evaluation of the excavation records, and, since she found no evidence in the original documentation of spring flowers, concluded that the length of time the burial was left open was less protracted.

The illustration showing Gansum's (2004a) interpretations of the Oseberg burial (Figure 6) is a valuable dissemination tool, placing the mound at the centre of a performative scene. Appealing as it is, it is nevertheless an over-simplification of the mound construction. One of the key points of this image is the

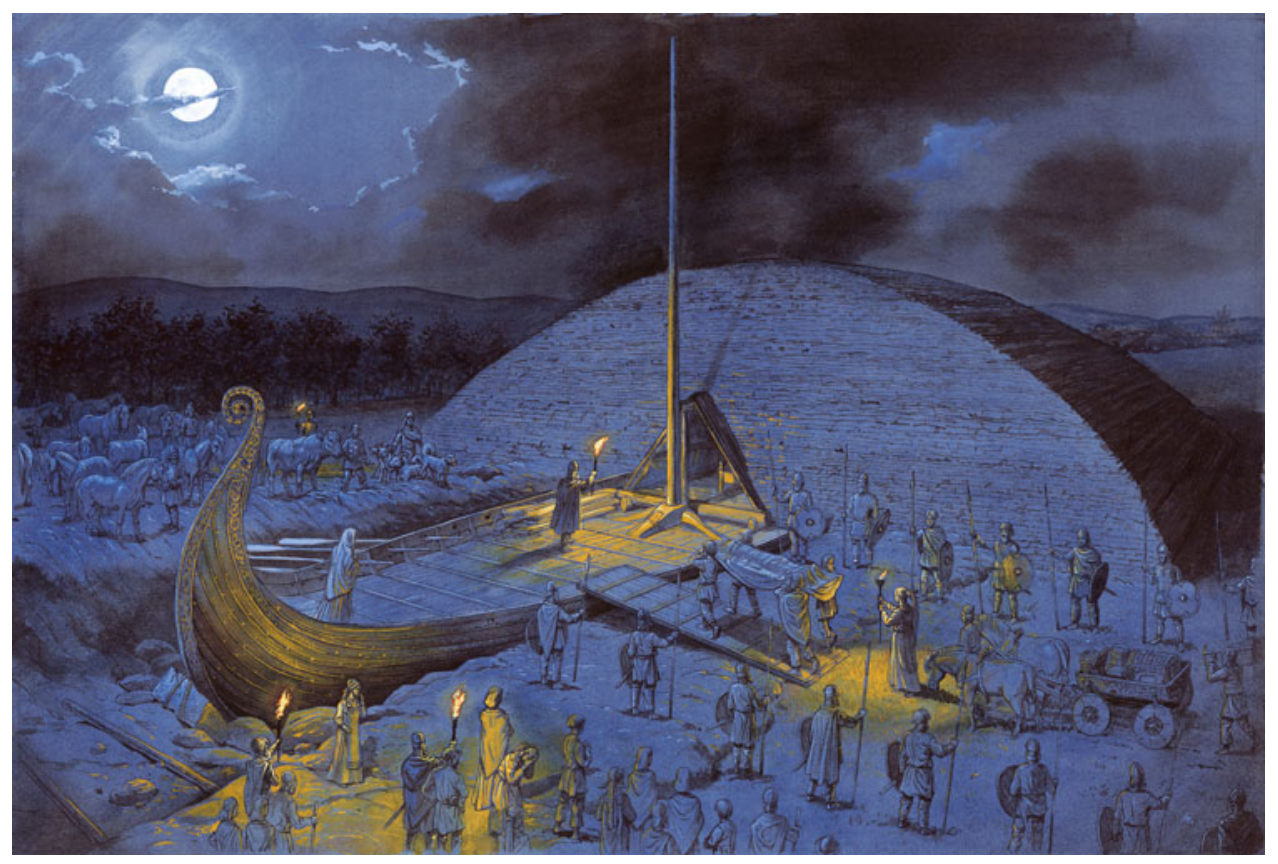

Figure 6. Gansum's (2004a) interpretations of the Oseberg burial during its funerary ceremony. (C) Anders Kvåle Rue, reprinted with permission. 
suggestion that the mound was built in two phases, with a divide over the central area. The images caught on camera and the original excavation drawings do show a line over the mound that suggests a divide, but other features complicate the picture: the layers within the mound suggest a complex series of events, from cutting down to rebuilding with stones, turves, and sediments.

Before considering the soils and sediments, it is worth examining the stones that covered the ship. It has been suggested that these stones were used to weigh down the ship and, with it, the dead (Bill, 2016). Shetelig (1917a) calls the feature a stone cairn, and the original section drawing (Figure 7) shows a cairn, rather than just stones covering the deck. This would have made the neat divide in the turf over the grave chamber, as shown in Figure 6, impossible, or one that revealed a cairn, rather than an open chamber. Upon excavation, the only part of the ship not covered by the cairn was the uppermost part of the chamber, which had been broken into in antiquity (Figure 8) (Bill \& Daly, 2012). Any stones covering the chamber would presumably have been removed to facilitate the break-in. This suggests that a cairn had been constructed over the entire chamber, and that the central divide in the turf cannot be directly interpreted as half the mound being constructed first, in order for the chamber to be accessible, and the final half of the mound being constructed later.

Moving on to the soils and sediment layers making up the mound, the stratigraphic boundaries, and more importantly the pedological properties of these layers, show significant variation. Whilst the extreme aft (back) sector of the burial may have had a topsoil buried in situ under the mound, this is absent from the fore sector of the mound. The 'front' half of the area to be occupied by the mound must have been stripped down to a considerable degree, removing the topsoil and upper subsoil and exposing the bluish, hydromorphic silty clay that dominates the lower subsoils in the locality. Hydromorphic soils are soils which have chemical and physical features generated by ground water and/or surface water saturation. Towards the rear of the ship, the section below the clear turf layers have areas that could belong to an

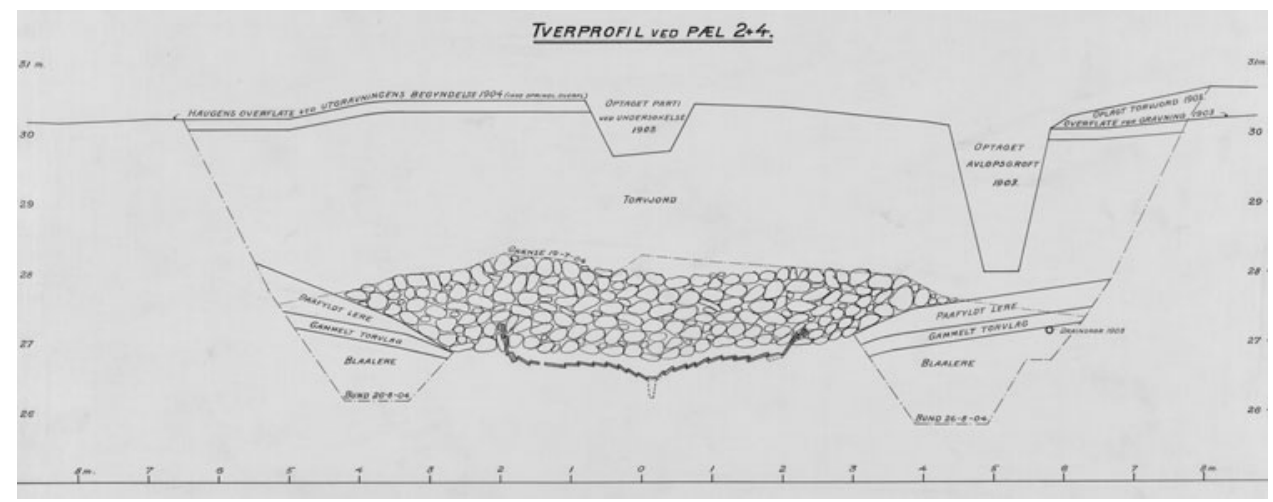

Figure 7. Section through the Oseberg mound, from the 1904 excavation. Note that the cairn covers the ship, except for the upmost part of the grave chamber, where the burial was disturbed by a robber trench. All sketches are available at www.musit.uio.no. (C) 2020 Museum of Cultural History, UiO / CC BY-SA 4.0, Image ID 05_8823_2_911_C55000. 


\section{OSEBERG}

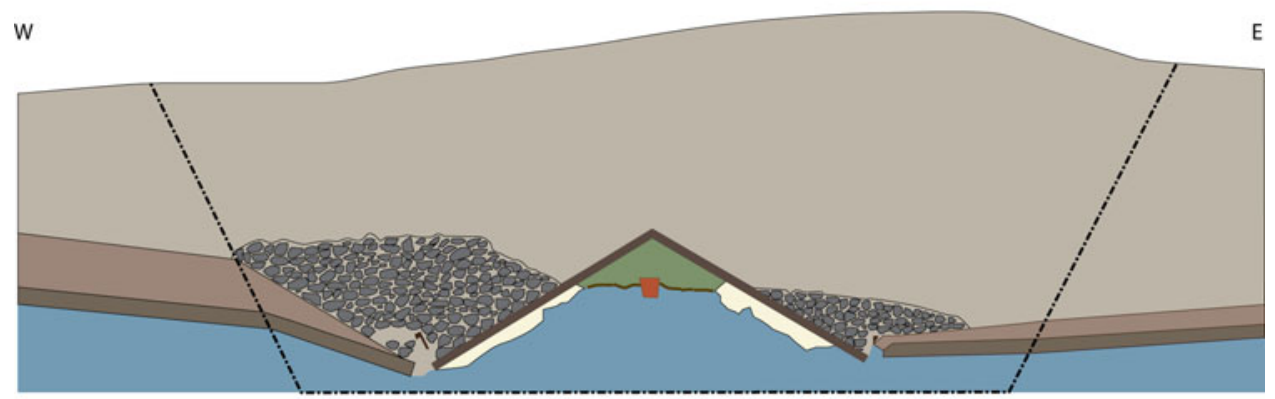

.... Excavation limits

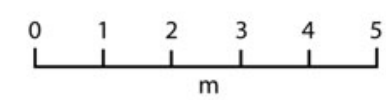

- Outline of grave chamber

Turf inside chamber

Grave goods in blue clay

Keel

$\square$ Upper turf mound
Stone cairn
Clay mound
Turf layer
Blue clay

Figure 8. Section redrawn from the original excavation of Oseberg. It is highly atypical for the types of soils present near Oseberg to have clearly identifiable blue clay (blaleire) directly under the turf layer. All sketches are available at www.musit.uio.no. (C) University of Oslo 2020, UiO / CC BY-SA 4.0, Image ID 05_8823_2_903_C55000.

undisturbed soil profile, as there is a suggestion of gradual interfaces and a reducing organic content as the depth increases (see supplementary material), which is an indication of a soil formed in situ. This potentially intact soil does not appear to extend all the way around the ship. This implies that areas towards the rear of the mound were left intact, whereas areas towards the front and the starboard were stripped of subsoil to varying degrees.

It is also clear that the mound is made of both redeposited material from $\mathrm{B}$ and $\mathrm{C}$ horizons (i.e. the upper and lower subsoil layers) and layered turf. From its appearance, the turf varies in its physical properties, suggesting that it came from more than one environment or parent material. This is perhaps what produces the line in the turf layers, although this is highly speculative since we do not know the timeframe for the cutting, storing, and placing of the turves. In their study of the turf, Holmboe describes vivianite, which was also found in the turves from Gokstad (Holmboe, 1917; Macphail et al., 2013). Vivianite is associated with wet to waterlogged conditions, and phosphate rich inputs such as human or animal waste (Karkanas \& Goldberg, 2018). At Gokstad, this was interpreted as turf cut from the wetter valley base, in an area that had been used as grazing land. It can, therefore, be suggested that the area near the Oseberg mound, or at least an area where the turf was sourced, was grazing land in the Viking period.

\section{The Sinking ShIP}

The notion that the Oseberg mound and ship had sunk by up to $3.5 \mathrm{~m}$ stems from observations made during excavation (Brøgger et al., 1917: 135). As burial mounds were supposed to be imposing, it was considered impossible that such an 
impressive and wealthy grave would be placed in a natural depression. However, size may have been but one aspect of these mounds, and choice of materials and details of construction may have been just as important. Moreover, whether sinkage occurred, and how it did so, can reveal details of the building process.

In Oseberg, Brøgger was sure he could follow the undisturbed buried topsoil in the section, concluding that the weight of the mound had caused the whole mound to sink by up to $3.5 \mathrm{~m}$. Shetelig's statement that the topsoil surface had been removed before the mound was erected seems initially contradictory, but it is likely that Shetelig was only referring to the removal of soil before placing the ship, and not the wider mound (Shetelig, 1917a: 210). As the ship is recorded as having been placed in a trench, this does not contradict the excavators' other observations (Brogger et al., 1917: 134-35).

Though it is difficult to challenge such observations based on images and their interpretations alone, there are two issues that can be considered. First, the deformation of saturated clay through slumping does not result in universal downward sinkage, but rather in the stabilization of the unstable mass (Figure 9). In addition, for slumping to occur and the groundmass to become so unstable, in these circumstances the water table must be breached. In the images of Oseberg (see supplementary material), it is quite clear that the deformed clay pushed up through from the underside of the ship and into the burial chamber (Brøgger et al., 1917; Bill, 2016). It is also apparent that, given the stratification encountered in excavation, this must have occurred before the reopening of the grave in the late Viking Age (Bill \& Daly, 2012; Bill, 2016). Such instabilities occur rapidly, which fits the interpreted order of events: the burial took place in $\mathrm{AD} 834$ or later and was already deformed when it was reopened after $\mathrm{AD} 953$.

The soils at Oseberg are also hydromorphic soils (i.e. epistagnic albeluvisols and luvic stagnosols (siltic)), which are characterized by silty clay soils that are periodically surface saturated (FAO, 2015; NIBIO, 2020). In addition, the epi prefix denotes the stagnic properties are mainly present in the upper $50 \mathrm{~cm}$ (FAO, 2015). The important aspect here is that the soil types present are typically wet from the surface and downwards, and poorly drained.

Second, the observed turf line forms a bowed shape, dipping toward the middle

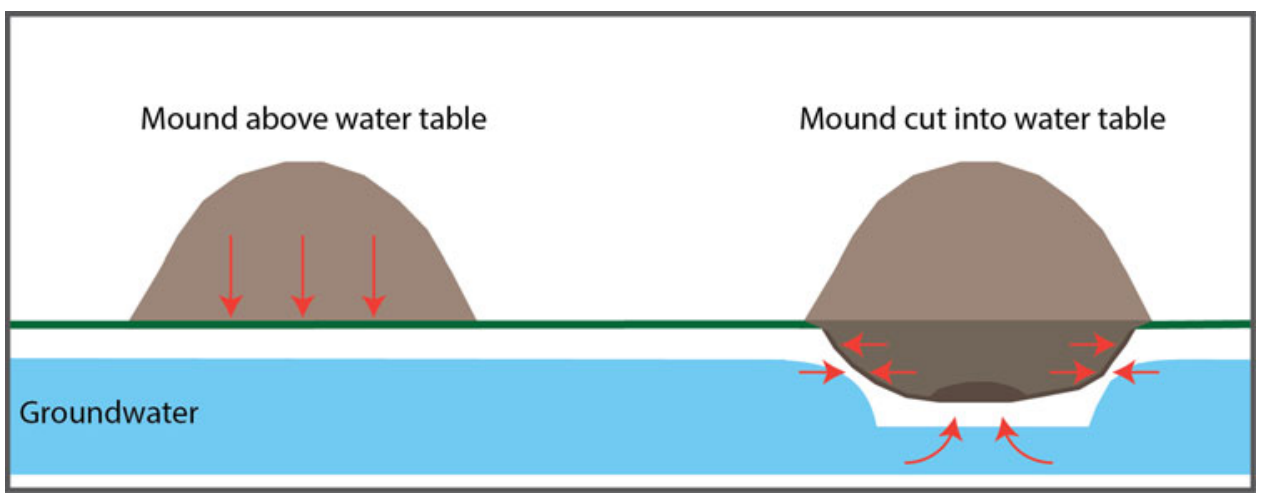

Figure 9. Simplified diagram illustrating the process of deformation under a mound if the water table is not breached (left) and breached (right). The arrows show the direction and force of movement. 
of the mound and ship. This is the line that convinced the excavators of the mound sinkage. For the rear to the midpoint on the port side, this could well represent the dipping of the buried topsoil line, but from the mid-point and to the fore, this is redeposited material used in mound construction, and not part of the original, pre-mound surface. Particularly towards the fore/prow of the ship, the lower sediments visible do not resemble a natural soil profile; the interfaces are so clear and abrupt that they appear as redeposited sediment layers that have remained quite homogenous, i.e. not mixed substantially with other soils or sediments. The sinkage hypothesis, especially a sinkage of no less than $3.5 \mathrm{~m}$, needs reassessing in light of the varied construction practices displayed. The deformation of material, as shown by the material rising through the deck of the Oseberg ship, suggests that it followed a process similar to that illustrated in Figure 9; this would have caused minor sinkage as the material slumped and filled the internal voids created by the burial chamber and ship. It is unlikely it equated to $3.5 \mathrm{~m}$.

Thus far, we have seen that the Oseberg mound was built of differing materials, placed in a sequence. To the rear, the original surface was covered in redeposited subsoil material, and then turf was stacked; towards the fore of the mound and ship, there is a truncated surface with redeposited subsoil material and stacked turf above. As Gansum (2004b: 171-74) suggested, the fore and the aft are constructed differently. When considering more than the turf alone, there is no neat central division arching over the ship. On the left side the lower horizons become truncated further towards the rear than the sharp division in the turf, whilst on the right-hand side these divisions are in tandem. This suggests that more than half of the mound area was dug down below the ground surface, which would have resulted in a very wet environment of slushy, blue silty clay. Although the perspective in these images can be misleading, it appears that most of the ship is located below the preserved topsoil line to the rear, implying the whole vessel was placed in a substantial trench.

The data from Gokstad can help illuminate the scale and construction of ship burial mounds. Over one hundred cores were taken either on the preserved flanks of the Gokstad mound or in its immediate vicinity. This provided fine stratigraphic detail not available for any of the other mounds considered in this article. The Gokstad coring data make it clear that before the mound was built, a large area approximating the diameter of the finished mound (c. $43.5 \times 48 \mathrm{~m}$ ) was first stripped of topsoil. The underlying gleyed B horizon material was then removed, sloping towards the centre of the mound. Toward the centre, the area was dug further down removing the lower subsoil horizons. This is a gleyed (waterlogged) C horizon, composed of marine-sourced blue silty clay, as at Oseberg. It appears that, once removed, these layers were kept quite separate, in that the redeposited layers of these materials show only minor visual differences connected to their structure. The depth of excavation was at least $1.5 \mathrm{~m}$, but, as the central part of the mound was inaccessible due to being backfilled with stones and gravel, the true depth is unknown. In a small section, in the northern side of the mound and to the rear of the ship, an area was left intact, i.e. the soils were not removed (Cannell et al., 2020).

At Gokstad, we can imagine the ship in its trench surrounded by a muddy pool of blue silty clay as the grave goods were carried over the preserved 'land-bridge' and onto the ship. In common with 
Grønhaug and Oseberg, the deck of the Gokstad ship was covered, this time with hazel fascines rather than bark and moss. The blue silty clay excavated from the lower layers was then placed around the ship to the third strake. Unlike Oseberg, we have no evidence for a cairn being placed over or around the Gokstad ship (Figure 10). The mound was built up of mixed upper subsoil in parts, but the majority was stacked turf placed over the blue clay-silt. The estimated volume of the marine-sourced blue silty clay suggests some must have been gathered from beyond the mound itself, and, again, kept 'clean' before being placed on the mound (Cannell, 2012; Cannell et al., 2020).

Both at Oseberg and Gokstad wetland turves were used for construction, and the value of the land they represent should not be underestimated. Wetland grazing, as attested in medieval sources, was important grazing land (Galloway, 2009). Whether this should be considered a 'sacrifice', as Gansum has suggested, is debatable, as this shines a solely economic light on the act (Gansum, 2004b). Indeed, using the term 'sacrifice' for grave goods and the earth itself is to view the elaborate and invested construction of these monuments in a very modern perspective on economics, wealth, and status. Whilst these are undeniably a part of the expression, we should not reduce these burial mounds to our understanding of agricultural economics. The temporal and earthly references within the monuments, the belief in the journey of the dead, and the dynamic expression in the mounds' construction should be equally central to interpretations.

\section{Poor Tune, Østfold}

The least well preserved of the Viking ships was found in 1867 at Rolsøy, in Østfold in eastern Norway, though only published some fifty years after its excavation by Olaf Rygh (Shetelig, 1917b). Although it had been speculated that there were three ships excavated in the area over the past 200-300 years, a recent review suggests there was only one (Bill, 2017). The burial dates to around AD 910 (Bonde \& Christensen, 1993). The burial mound sits on luvic stagnosols, which are again hydromorphic soils, and is quite similar to the other ship burials described above. The ship, which is estimated to have been around nineteen or twenty metres long (Shetelig, 1917b: 11; Paasche, 2010: 163), was placed in a trench so it was level with the surface (Shetelig, 1917b), meaning the gunwales, although not preserved at Tune, would have been

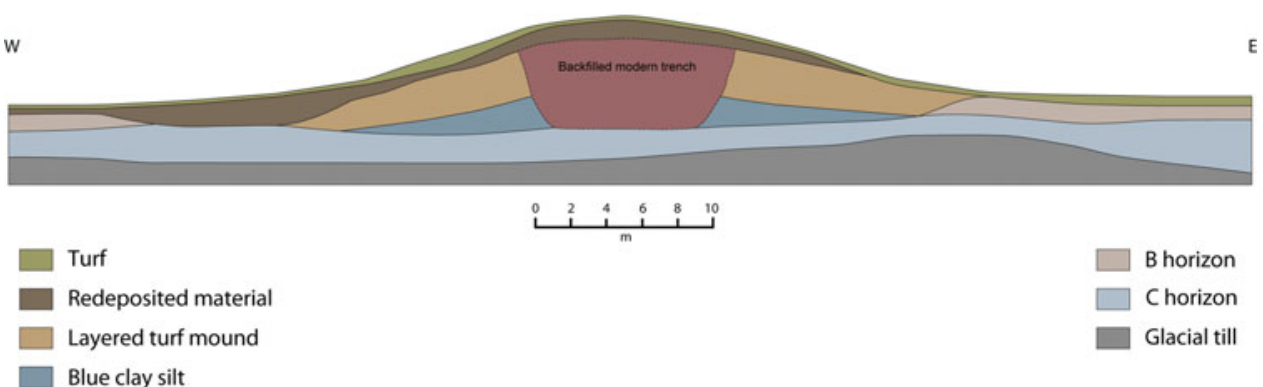

Figure 10. Simplified section through the Gokstad burial mound (after Cannell et al., 2020: fig. 7). 
level with the ground. Considering the ship was c. $1.3 \mathrm{~m}$ high from the gunwales to the base of the keel, the ship was in a sizeable trench, as were the Gokstad and Oseberg ships. The deck of the ship was strewn with juniper and moss before being packed with blue silty clay.

The excavation was prompted by the removal, from the mid-1800s onwards, of soil from the mound for use as fertilizer on a sandy field, which exposed the ship. This suggests turf or organic rich soils were used in the mound construction. Arntzen, who assisted in the excavation, described the upper soils of the mound as muld, i.e. an organic, peaty soil. The lower mound was hard packed blue clay, which continued to the base of the excavation (Shetelig, 1917b: 4). If the turf was directly over the blue clay, then, as Shetelig observed, the area would have been stripped before the mound was constructed. But this cannot have simply involved the removal of the topsoil; the subsoil (B horizon) was also removed. In these soil conditions, a typical soil profile would have an upper subsoil (B horizon) of mid-brown silty clay, with iron mottles increasing with depth towards the wetting front and the lower, grey-blue silty clay. The blue-grey colour comes from iron being reduced in anaerobic conditions below the water table. This is often $50 \mathrm{~cm}$ or more below the surface on these marinesourced sediments. Therefore, this B horizon must have been removed during the mound construction for the excavators to discover turf directly over blue silty clay, the latter perhaps wholly or partly redeposited. The lack of further documentation, typical of the time of excavation, is compounded by the fact that most of the valuable objects that were undoubtedly buried with the ship were removed, both in antiquity in a plundering episode and more recently by curious local people. This dearth of portable objects, when compared to Oseberg and Gokstad, has arguably led to the mound and ship being paid less attention than others.

\section{Discussion}

Here, no attempt has been made to present a complete catalogue of ship burials from Norway; for example, the Myklebostad and Borre ship burials have not been included, nor has the possible ship's grave from Tønsberg in Vestfold. Instead, the aim of my research has been to show that the connections between the selected burial mounds go beyond the presence of a ship, break-ins in antiquity, and the provenance of timbers.

There are undoubtable similarities in the mound constructions presented here, perhaps with some exceptions in Grønhaug. Whether the latter is different because it is possibly the earliest of the examples presented here, or because its builders chose to either re-use an older burial or align a new one with the nearby Bronze Age mounds, must remain unresolved. If it was 'purpose built' for the ship, then the ship was curiously placed in a mound that shared traits with other local Bronze Age mounds. The other mounds-Storhaug, Oseberg, Gokstad, and Tune- -have striking similarities in their construction details. All appear to have had substantial parts, or indeed all, of the topsoil under the mound removed before the mound was built, and at Oseberg, Gokstad, and Tune large areas were dug down to a considerable depth. This was to accommodate the ship, but perhaps also to create a scene with the ship in a pool of muddy water.

In Storhaug, the one metre thick layers of charcoal speak of an intense or longlasting process of gathering, producing, processing, and placing vast quantities of transformed material on the mound. The burials also show that the material was carefully segregated. The bluish silty clay 
was not mixed with the turf or redeposited material from the upper subsoil (B horizon), and the moss was only on the ships' deck. This separation implies that these materials were considered individual entities with differing properties, and their separation was necessary from either a cultural or a practical point of view, or perhaps both. They represented, and referenced, different things, and they were treated with distinct care. These materials came from different locations in the landscape, from within or under the living surface of that landscape, perhaps referencing different components, including naked soil, fertile land, growing turf, and moss. The contrasting colours that result from keeping these layers segregated would have been an arresting sight as the mound was being built; consider the black charcoal against the reddish-yellow clay loams in Storhaug, or the blue clay pool at the base of Oseberg and Gokstad. This effect was part of the burial process and the creation of the performative scene. The interaction with these materials was performative in itself, and the selection of materials and the references they contained may have invoked memories of earlier burials.

To interpret the similarities in construction and set them in context, the performative aspects of the materials, and Viking Age funerary rites, need to be considered. In his study of Gotlandic picture stones, Andrén noted that the iconography of the stones located on an estate boundary was linked. When traced from one stone to the next, it became clear that the images told the story of Sigurðr and the dragon Fafnir (Andrén, 1993). Moreover, these stones are thought to commemorate successive generations of a family or dynasty. Price (2012) has noted other instances of distinct local practice spanning several generations, suggesting that certain stories or performances were strongly connected to funerary rites, rites which expressed a desired identity and sense of belonging. Continuity in the materials used, human engagement with them, and the references they contain may have been used to tie the deceased to the story or origin myth (or both) to which they were intended to relate. This practice could span time and space, being retained in the social memory of those who identified with a particular practice or tale.

Human engagement with materials creates references and associations through performative acts, where both are involved and invested. Within this process, experimentation and creativity results in unique expressions and forms that can nonetheless retain or reshape the references between materials and humans. In the burials presented here, a unique form of burial was created by repetition, or citation. No single burial mound discussed here is identical, but common features linked to the gathering, sculpting, and placing of earth-sourced materials in an arrangement around the entrenched ship created purposeful references to previous burials, and performances of a tale. Bill (2019) has speculated that the stories recreated and reinterpreted in these ship burials and contemporary ship settings have potential links to the Skjoldungar myth, or at least to idealized, mythical origins.

If this is the case, then we need to consider whether the building of ship burial mounds reflects more broadly differing local practices related to other stories and performances enacted in mortuary behaviour. Gansum (2004b) emphasized that the erection of a mound was part of the performative aspects of mortuary rites; the mound materials themselves were involved in the rites linking the living to the deceased. Here, I have suggested that the careful selection and layering of the materials used in the mounds is part of this performance. If we are to advance our understanding of Viking Age mortuary practice, we must 
consider mounds as an essential performative element in funerary rites, and not simply as material that covered a burial, to be measured by mound size only.

\section{Conclusion}

Viking Age ship burial mounds cannot be seen as purely a linear evolution in mortuary rites, from earliest to latest. We must examine them within a temporal focus but without being overly linear, as these burials simultaneously reach backward and forward in time: they are connecting to and referencing the past (real and mythical) and also creating permanent references in the landscape intended to remain into the future. We must also see the mounds' temporal connection to the mythical, social, and physical past, as expressed through performative engagement with the earthsourced materials themselves. In the mythical realm, the connections are multi-temporal, and myths themselves are neither static nor linear, nor directly evolutionary. They are renegotiating the past by creating, upholding, and recreating references, shaping the present, and transforming the landscape as individual entities within a whole. The result is a complex, expressive mound which ultimately becomes hidden and transformed by the regenerative nature of the materials used. The scars in the landscape, and the patchwork of turf over the mounds as it slumps, changes, and regrows, encapsulate the layers within and the references they contain.

Whether Grønhaug on Karmøy-probably one of the earliest of the large Viking ship burials in Norway-was a re-used Bronze Age burial mound is uncertain. Assuming that Grønhaug was originally a Bronze Age mound, a ship was placed in it in or after $\mathrm{AD} 779$, in all likelihood around 790-95, based on the average active use other comparable ships saw before being used in funerary rites (Bonde \& Stylegar, 2016). The Oseberg mound was constructed some forty or fifty years later, with large stones in a cairn formation covering the ship. Was this weighing down of the dead for real or supernatural reasons (Bill, 2016) or was it for bringing temporal references to this newer burial? Our obsession with dating things and creating tight chronologies cannot be transferred to the past, when the relative age, or placing one thing before another, was the central purpose (Bradley, 2002; Lucas, 2015). In re-using and referencing the past in these burials, the connotations of belonging, and perhaps legitimacy were defined by the use of a pile of stones. As far as the records allow, only Grønhaug and Oseberg contain large central cairns; yet the valley base location of Oseberg is more comparable to the cairnless sites of Gokstad and Tune.

There are undoubtedly connections between all these burials, beyond the range of objects and their use as ocean-going ships. The evidence available points to many common traits in the way the mounds were built. All but Grønhaug were dug down to accommodate a ship, and all but Grønhaug were stripped of topsoil (and subsoil) to some degree. All contained wetland turves, which, aside from being excellent building material (Milek, 2012), also had connotations in the Viking Age to liminal places between mythical realms (Lund, 2008). Possibly the ships lay in pools of water. They were ready to sail, but it was also in a liminal, multi-temporal, and referential space, and a scene created for the drama of the burial, a burial referring to those before and those to come.

\section{Supplementary Material}

To view supplementary material for this article, please visit https://doi.org/10. 1017/eaa.2020.63. 


\section{ACKNOWLEDGEMEnTs}

The research presented in this article is funded by the Research Council of Norway, under the project 'Using the Past in the Past. Viking Age Scandinavia as a Renaissance?' (grant code 250590). The author wishes to thank the project PI, Julie Lund, and project member Stine Urke Brunstad for their significant support. This work builds on earlier research by Terje Gansum and Jan Bill, who have been encouraging and supportive throughout. Lars Gustavsen kindly edited the figures. The author is deeply indebted to colleagues for their comments and improvements to this article, as well as the three reviewers who provided constructive feedback on improving the text and figures.

\section{REFERENCES}

Aannestad, H.L. \& Glørstad, A.Z.T 2017. Kvinner og båtbegravelse i vikingtiden. In: K. Kjesrud \& N. Løkka, eds. Dronningen: $i$ vikingtid of middelalder. Oslo: Scandinavian Academic Press, pp. 155-78. Acksel, A., Giani, L., Stasch, C., Kühn, P., Eiter, S., Potthoff, K., et al. 2019. HumusRich Topsoils in SW Norway: Molecular and Isotopic Signatures of Soil Organic Matter as Indicators for AnthropoPedogenesis. CATENA, 172: 831-45.

Andrén, A. 1993. Doors to Other Worlds: Scandinavian Death Rituals in Gotlandic Perspectives. Journal of European Archaeology, 1: 33-56.

Back Danielsson, I.M. 2007. Masking Moments: The Transitions of Bodies and Beings in Late Iron Age Scandinavia. Stockholm: University of Stockholm.

Barad, K. 2007. Meeting the Universe Halfway: Quantum Physics and the Entanglement of Matter and Meaning. Durham, NC: Duke University Press.

Bill, J. 2013. Revisiting Gokstad: Interdisciplinary Investigations of a Find Complex Excavated in the 19th Century. In: S. Brather, ed. Fundmassen. Innovative
Strategien zur Auswertung frühmittelalterlicher Quellenbestände, Esslingen 8.-10. November 2011. Stuttgart: Konrad Theiss.

Bill, J. 2016. Protecting Against the Dead? On the Possible Use of Apotropaic Magic in the Oseberg Burial. Cambridge Archaeological Journal, 26: 141-55.

Bill, J. 2017. Skipsgrav eller skipsgraver på Rolvsøy. Om Tuneskipets utgravningshistorie. Viking, 80: 89-106.

Bill, J. 2019. The Ship Graves on Kormt and Beyond. In: D. Skre, ed. Rulership in 1st to 14th Century Scandinavia Royal Graves and Sites at Avaldsnes and Beyond. Berlin \& Boston: De Gruyter, pp. 305-92.

Bill, J. \& Daly, A. 2012. The Plundering of the Ship Graves from Oseberg and Gokstad: An Example of Power Politics? Antiquity, 86: 808-24.

Bonde, N. \& Christensen, A.E. 1993. Dendrochronological Dating of the Viking Age Ship Burials at Oseberg, Gokstad and Tune, Norway. Antiquity, 67: 575-83.

Bonde, N. \& Stylegar, F.-A. 2009. Fra Avaldsnes til Oseberg: dendrokronologiske undersøkelser av skipsgravene fra Storhaug og Grønhaug på Karmøy. Viking, 72: 149-68.

Bonde, N. \& Stylegar, F.-A. 2016. Between Sutton Hoo and Oseberg: Dendrochronology and the Origins of the Ship Burial Tradition. Danish Journal of Archaeology, 5: 19-33.

Bradley, R. 2002. The Past in Prehistoric Societies, London: Routledge.

Bradley, R. 2015. Piecing Together a Past. In: M. Díaz-Guardamino, L. García Sanjuán \& D. Wheatley, eds. The Lives of Prehistoric Monuments in Iron Age and Medieval Europe. Oxford: Oxford University Press, pp. 325-41.

Brøgger, A.W., Shetelig, H. \& Falk, H. 1917. Osebergfundet. Bind I. Kristiania: Universitetets Oldsaksamling.

Cannell, R.J.S. 2012. Archaeological Investigation of the Gokstad Mound 2011. Unpublished archive report. Oslo: Museum of Cultural History, University of Oslo.

Cannell, R.J.S., Bill, J. \& Macphail, R. 2020. Constructing and Deconstructing the Gokstad Mound. Antiquity, 94: 1278-95.

Christensen, A.E. 1959. Færingen fra Gokstad. Viking, 23: 57-70. 
Dobat, A.S. 2015. Viking Stranger-Kings: The Foreign as a Source of Power in Viking Age Scandinavia, or, Why There Was a Peacock in the Gokstad Ship Burial? Early Medieval Europe, 23: 161201.

FAO 2015. World Reference Base for Soil Resources 2014. International Soil Classification System for Naming Soil and Creating Legends for Soil Maps. Rome: Food and Agriculture Organization of the United Nations.

Galloway, J.A. 2009. Storm Flooding, Coastal Defence and Land Use Around the Thames Estuary and Tidal River c. 12501450. Journal of Medieval History, 35: 171-88.

Gansum, T. 2002. Fra jord til handling. In: K. Jennbert, A. Andrén \& C Raudevere, eds. Plats och Praxis - studier av nordisk fökristen ritual. Lund: Nordic Academic Press.

Gansum, T. 2004a. Gåten Oseberg. Levende Historie, 4: 32-35.

Gansum, T. 2004b. Hauger som konstruksjoner: arkeologiske forventninger gjennom 200 år. Gotars Serie B. Gothernburg Archaeological Thesis No 33. Gothenburg: University of Gothenburg.

Given, M. 2018. Conviviality and the Life of Soil. Cambridge Archaeological Journal, 28: 127-43.

Gunnell, T. 2006. "Til holts ek gekk..." The Performance Demands of Skírnismál, Fáfnismál and Sigrdrígumál in Liminal Time AND Scared Space. In: A. Andrén, K. Jennbert \& C. Raudevere, eds. Old Norse Religion in Long-Term Perspectives. Lund: Nordic Academic Press.

Holck, P. 2006. The Oseberg Ship Burial, Norway: New Thoughts on the Skeletons from the Grave Mound. European Journal of Archaeology, 9: 185-210.

Holck, P. 2009. The Skeleton from the Gokstad Ship: New Evaluation of an Old Find. Norwegian Archaeological Review, 42: 40-49.

Holmboe, J. 1917. Botanisk Undersøkelse av Torven i Oseberghaugen. In: A.W. Brøgger, H. Shetelig \& H. Falk, eds. Osebergfundet. Bind I. Kristiania: Universitetets Oldsaksamling.

Jones, A.M. 2007. Memory and Material Culture: Tracing the Past In Prehistoric Europe. Cambridge: Cambridge University Press.
Jones, A.M. 2012. Prehistoric Materialities: Becoming Material In Prehistoric Britain and Ireland. Oxford: Oxford University Press.

Karkanas, P. \& Goldberg, P. 2018. Phosphatic Features. In: G. Stoops, V. Marcelino \& F. Mees, eds. Interpretation of Micromorphological Features of Soils and Regoliths (second ed.) Amsterdam: Elsevier, pp. 323-46.

Lorange, A. 1888. Storhaugen paa Karmøen : nyt skibsfund fra vikingtiden. Bergens Museums Aarsberetning, 4: 1887.

Lucas, G. 2015. Archaeology and Contemporaneity. Archaeological Dialogues, 22: $1-15$.

Lund, J. 2008. Banks, Borders and Bodies of Water in a Viking Age Mentality. Journal of Wetland Archaeology, 8: 53-72.

Macphail, R., Bill, J., Cannell, R., Linderholm, J. \& Rødsrud, C.L. 2013. Integrated Microstratigraphic Investigations of Coastal Archaeological Soils and Sediments in Norway: The Gokstad Ship Burial Mound and its Environs Including the Viking Harbour Settlement of Heimdaljordet, Vestfold. Quaternary International, 315: 131-46.

Milek, K.B. 2012. Floor Formation Processes and the Interpretation of Site Activity Areas: An Ethnoarchaeological Study of Turf Buildings at Thverá, Northeast Iceland. Journal of Anthropological Archaeology, 31: 119-37.

Mundal, E. 2018. Avaldsnes and Kormt in Old Norse Written Sources. In: D. Skre, ed. Avaldsnes: A Sea Kings' Manor in FirstMillennuim Western Scandinavia. Berlin \& Boston: de Gruyter.

Myhre, B. ed. 2015. For Viken ble Norge: Borregravfeltet som religios og politisk arena. Tønsberg: Vestfold fylkeskommune.

NIBIO (Norwegian Institute for Bioeconomy Research) 2020. Kilden. https://kilden. nibio.no/

Nicolaysen, N. 1882. Langskibet fra Gokstad ved Sandefjord. Kristiania: Cammermeyer.

Nordeide, S.W. 2011. Death in Abundace Quickly! The Oseberg Ship Burial in Norway. Acta Archaeologica, 82: 7-15.

Opedal, A. 1998. De glemte skipsgravene: makt og myter på Avaldsnes. Stavanger: Arkeologisk Museum i Stavanger.

Paasche, K. 2010. Tuneskipet: dokumentasjon og rekonstruksjon (unpublished $\mathrm{PhD}$ 
dissertation, Institute of Archaeology, Conservation and History, University of Oslo).

Pedersen, U., Andersen, T., Simonsen, S. \& Erambert, M. 2016. Lead Isotope Analysis of Pewter Mounts from the Viking Ship Burial at Gokstad: On the Origin and Use of Raw Materials. Archacometry, 58: 148-63.

Price, N. 2010. Passing into Poetry: VikingAge Mortuary Drama and the Origions of Norse Mythology. Medieval Archaeology, 54: 123-56.

Price, N. 2012. Mythic Acts: Material Narratives of the Dead in Viking Age Scandinavia. In: C. Raudevere \& J.P. Schjødt, eds. More than Mythology. Lund: Nordic Academic Press, pp. 13-46.

Price, N. 2014. Nine Paces from Hel: Time and Motion in Old Norse Ritual Performance. World Archaeology, 46: 17891.

Seal, J. 2003. Building a Copy of the Gokstad Faering. International Journal of Nautical Archaeology, 32: 238-45.

Shetelig, H. 1902. En plyndret baadgrav. Bergens Museums Aarbok, 8: 3-14.

Shetelig, H. 1912. Vestlandske graver fra jernalderen. Bergen: Grieg.

Shetelig, H. 1917a. Oseberggraven. In: A.W. Brøgger, H. Shetelig \& H. Falk, eds. Osebergfundet Bind I. Kristiania: Universitetets Oldsaksamling.

Shetelig, H. 1917b. Tuneskibet. Kristiania: Universitetets Oldsaksamling.

Skre, D. 2018. Aristocratic Presence Along the Karmsund Strait 2000 BC-AD 1368. In: D. Skre, ed. Avaldsnes: A Sea Kings' Manor in First-Millennuim Western Scandinavia. Berlin \& Boston: de Gruyter.

Stylegar, F.-A. \& Reiersen, H. 2018. The Flaghaug Burials. In: D. Skre, ed. Avaldsne: A Sea-Kings' Manor in First
Millennium Western Scandinavia. Berlin \& Boston: de Gruyter.

Thäte, E.S. 2007. Monuments and Minds: Monument Re-use in Scandinavia in the Second Half of the First Millennium AD. Lund: Wallin \& Dalholm.

Thoresen, P. 1980. Kongshaugen på Gokstad. Sandefjord: Sandar historielag.

Vedeler, M. 2011. Fra Silkeveien til Oseberg. Viking, 74: 137-48.

Williams, H. 1998. Monuments and the Past in Early Anglo-Saxon England. World Archaeology, 30: 90-108.

Williams, H. 2006. Death and Memory in Early Medieval Britain. Cambridge: Cambridge University Press.

Williams, H. 2016. Viking Mortuary Citations. European Journal of Archaeology, 19: 400-14.

\section{BiograPHicAl Notes}

Rebecca Cannell's research combines her past analytical experience of archaeological soils with temporal approaches to mortuary practice in the Viking Age. As soils are a key resource, human interactions with soils and their landscapes are a gateway to understanding past and present perceptions of the world. The author is currently applying this approach to Viking Age burial mounds.

Address: Department of Archaeology, Conservation and History, Faculty of Humanities, University of Oslo, Postboks 1008 Blindern, Oslo. [email: rebecca. cannell@iakh.uio.no]. ORCID: 00000001-7416-8189.

\section{L'essence des tertres : qualités référentielles des sols utilisés dans la construction de tumuli contenant des navires de l'époque viking}

L'auteur de cet article examine les détails relatifs à la construction de tertres érigés au-dessus de grands navires vikings en Norvège et démontre qu'ils faisaient partie intégrale des rites funéraires. Certains éléments répétés dans leur construction les distinguent, les démarquant comme des monuments potentiellement uniques; ces caractéristiques suggèrent que leurs créateurs connaissaient les qualités des matériaux qu'ils utilisaient et révèlent leurs rapports au sein des tertres. L'examen des qualités référentielles des sols utilisés dans la construction de divers tumuli, ainsi que les connections entre sols, sédiments et autres 
matières minérales et végétales employés dans ces tertres, est mis en rapport avec le paysage culturel. Le choix de matériau et la situation des monuments dans le paysage étaient des éléments essentiels des cérémonies funéraires, créant une scène pour leur représentation et pour la création d'une mémoire sociale commune. Translation by Madeleine Hummler

Mots-clés: époque viking, tertres funéraires, sols archéologiques, navires vikings, Norvège, qualités référentielles

\section{Kernbetrachtungen: die referenziellen Eigenschaften von Erdstoffen in wikingerzeitlichen Schiffsgrabhügeln}

Die Autorin dieses Artikels untersucht die bautechnischen Eigenschaften von Grabhügeln, welche über große Schiffe in der Wikingerzeit in Norwegen errichtet wurden, und zeigt, dass die Errichtung dieser Denkmäler ein integraler Teil der Begräbnisrituale bildete. Darüber hinaus deuten wiederholt verwendete Bauelemente, die potenziell eigenartig für diese Art von Denkmälern sind, auf eine Kenntnis der spezifischen Eigenschaften der Materialien und deren Zusammenbänge innerbalb der Grabbügel. Die Beziehungen innerbalb und zwischen den Grabhügeln, sowie die Verknüpfungen mit Erde, Sedimenten und anderen Erdstoffen, werden im Verbältnis zur Kulturlandschaft betrachtet. Die Wabl von Materialien und die Lage der Grabhügel in der Landschaft waren für die Durchführung von Bestattungszeremonien und für die Schaffung eines einheitlichen sozialen Gedächtnisses grundsätzlich. Translation by Madeleine Hummler

Stichworte: Wikingerzeit, Grabhügel, archäologische Erdschichten, Wikingerschiffe, Norwegen, Referenzialität 